Ilmu Pertanian (Agricultural Science)

Vol. 4 No. 2 August, 2019: 76-84

Available online at http://journal.ugm.ac.id/jip

DOI: doi.org/10.22146/ipas.36680

ILMU PERTANIAN

(AGRICULTURAL SCIENCE)

\title{
Growth and Yield Response of Maize (Zea mays L.) on Acid Soil to Different Rates of Humic Acid and NPK Fertilizer
}

\author{
Putri Wulandari ${ }^{1}$, Endang Sulistyaningsih ${ }^{1 *}$, Suci Handayani² and Benito Heru Purwanto ${ }^{2}$ \\ ${ }^{1}$ Department of Agronomy, Faculty of Agriculture, Universitas Gadjah Mada \\ Jln. Flora no. 1, Bulaksumur, Sleman, Yogyakarta 55281, Indonesia \\ ${ }^{2}$ Soil Science Department, Faculty of Agriculture, Universitas Gadjah Mada \\ Jln. Flora no. 1, Bulaksumur, Sleman, Yogyakarta 55281, Indonesia \\ *Corresponding author: endangsih@ugm.ac.id
}

Received: 03 ${ }^{\text {rd }}$ July 2018; Revised: $13^{\text {rd }}$ August 2018; Accepted: $11^{\text {st }}$ June 2019

\begin{abstract}
The main constraint in the extensification of maize on the dry land of acid soil is the low availability of $\mathrm{P}$ in soil. This study aimed to determine the effect and the optimal dose of humic acid on the growth and yield of maize on acid soil. This research was conducted from February to May 2017 at Tri Dharma Field Laboratory, Faculty of Agriculture, Gadjah Mada University. Acid soil with low P availability used was from sub-district Cigudeg and Jasinga, West Java. The research was arranged in Randomized Complete Block Design (RCBD) with 2 factors. The first factor was maize cultivar, namely Bisi 2 and Pioneer 35. The second factor was the rate of humic acid and NPK fertilizer, consisting of $0 \mathrm{~kg} \cdot \mathrm{ha}^{-1}$ (without) NPK and $0 \%$ (without) humic acid, NPK $+0 \%$ (without) humic acid, NPK $+5 \%$ humic acid, NPK $+10 \%$ humic acid, and NPK $+15 \%$ humic acid. NPK fertilizer applied was NPK 16:16:16 at a dose of 350 kg.ha-1. The results showed that humic acid application on acid soil increased C-humic content in the soil, soil P availability, total dry weight of the plant, and kernel dry weight at harvest (15 weeks after planting). The increase in soil P availability did not improve the plant growth but increased the accumulation of plant biomass. The application of humic acid at $15 \%\left(52.5 \mathrm{~kg} \cdot \mathrm{ha}^{-1}\right)$ combined with NPK fertilizer on acid soil significantly increased total dry weight of plant and kernel dry weight up to $13.14 \%$ and $21.81 \%$, respectively, thus, it is recommended for maize cultivation on acid soil.
\end{abstract}

Keywords: Humic acid, acid soil, corn.

\section{INTRODUCTION}

Maize is an important crop with multiple uses, which include the uses for food, industrial material, and bioenergy. The demand on maize for industrial material continuously soared in 2011-2015 from 3.67 million tons in 2011 to 3.88 million tons in 2015 (Kementerian Pertanian, 2016). Hence, it is necessary to increase maize production through agricultural intensification and extensification. Agricultural intensification is the management for maintaining food production without forfeiting natural resources for future generations by keeping it in balance with environmental function. The use of superior seed and good field management are some ways to improve agricultural production. The hybrid maize cultivars are widely cultivated to respond the environmental stress by improving morphological, physiological and yield capabilities (Sajedi et al., 2010). Bisi 2 is one of the widely cultivated maize cultivars in Indonesia. This cultivar was released in 1995 , and it has a potential yield up to 13 tons ha ${ }^{-1}$ with 8.9 tons $\mathrm{ha}^{-1}$ as the average yield. This cultivar also has a good capability of growing on lowland up to $1000 \mathrm{~m}$ above sea level (Badan Penelitian dan Pengembangan Tanaman Pertanian, 2012). In 2016, cultivar Pioneer 35 was released as a maize cultivar that has a potential yield up to 12.1 tons ha-1 with 9.2 tons ha-1 as the average yield.

Maize production can be increased through corn field expansion. In Indonesia, $79 \%$ of maize field are located on dry land (Zubachtirodin et al., 2008). Indonesia has 148 million ha of dryland resources. However, the varying climates and high rainfall lead to high loss of base content in the soil, causing 102.8 million ha of dry land to turn into acid soil (Mulyani 
et al., 2009). Acid soil has low $\mathrm{pH}$, less than 5.5, low content of macro nutrient elements, and high micro nutrient availability, which is poisonous for plant. Acid soil has a capacity in P fixation due to high levels of iron $(\mathrm{Fe})$, manganese $(\mathrm{Mn})$, and aluminum (Al), making P elements in the soil become unavailable for plant. The previous studies have reported that acid soil condition inhibited the growth of plant height, increased the anthesis to silking interval and decreased the yield on susceptible maize cultivars (Suwardi and Azrai, 2013). Unavailability of P becomes a major problem in acid soils because there is an inhibition on root growth, thus, affecting the nutrient uptake and shoot growth of plant. The soil $\mathrm{pH}$ can be increased by lime application $\left(\mathrm{CaCO}_{3}\right)$. However, the dose of the lime required is so high, reaching 20 ton. ha ${ }^{-1}$, that it leads to $\mathrm{P}$ deficiency due to $\mathrm{P}$ absorption by $\mathrm{Ca}$ (Haynes and Mokolobate, 2001).

Humic acid is the result of organic material decomposition that supports plant growth and yield directly or indirectly when it applied to acid soil. Functional groups of humic acids such as - $\mathrm{COOH}-$, -OH phenolate and -OH alcoholate bind with metal ions such as Al and decrease hydrogen bonds, and increasing $\mathrm{pH}$ in acid soil (Haynes and Mokolobate, 2001). Soil pH enhancement is followed by increased availability of $\mathrm{P}, \mathrm{N}$, and other macro nutrients in the soil due to increasing soil CEC, buffering capacity, and soil microorganisms (Tan, 2003).

Daur and Bakhashwain (2013) reported that the application of $25 \mathrm{~kg}$.ha- $\mathrm{o}^{-1}$ of humic acid to saline soil improved leaf area, dry weight, and mineral and protein content at 60 days after planting in R 1 (flowering) due to the increasing root growth, which improved the efficiency of water and nutrient uptake. The application of humic acid added to compost reduced toxicity caused by $5 \mathrm{ppm}$ of $\mathrm{Zn}$ in former mine and improved the plant height of Entorolobium cyclocarpum (Jacq.) Griseb (Fauziah, 2009). Other result showed that the application of humic acid to clay loam soil with $\mathrm{pH}$ of 6-7 improved the kernel weight of maize (Azeem et al., 2014). Humic acid application has been reported on different plants under different environmental conditions. There were some repots informing the effects of humic acid application. Nevertheless, there were limited information on the effect of the application of humic acid combined with NPK fertilizer on the growth and yield of maize on acid soil. Therefore, the objectives of this research were to study the effects of NPK and humic acid application on maize growth and yield on acid soil, and to determine the optimal dose of humic acid applied to acid soil for improving the growth and yield of maize.

\section{MATERIALS AND METHODS}

This research was conducted from February to May 2017 at Tri Dharma field laboratory, Faculty of Agriculture, Universitas Gadjah Mada. The research was arranged in Randomized Complete Block Design (RCBD) of 2 factors with 2 sampling locations as block or replication, in which each replication consisted of 3 sample plants that were harvested at 15 weeks after planting (WAP). The research used acid soil from two sampling points, namely sub-district Cigudeg and Jasinga, West Java, as block.

The first factor was maize cultivar (Bisi 2 and Pioneer 35). The second factor was dose of humic acid extract, consisting of without fertilizer and humic acid, NPK fertilizer without humic acid, NPK fertilizer $+5 \%$ humic acid $\left(17.5 \mathrm{~kg} \cdot \mathrm{ha}^{-1}\right)$, NPK fertilizer $+10 \%$ humic acid $\left(35 \mathrm{~kg} \cdot \mathrm{ha}^{-1}\right)$, and NPK fertilizer $+15 \%$ humic acid $\left(52.5 \mathrm{~kg} \cdot \mathrm{ha}^{-1}\right)$. The fractionation of humic acid was from organic cow manure, which were homogenized with $0.1 \mathrm{~N}$ $\mathrm{NaOH}(1: 10)$ and then filtered by whatman 42 filter paper. The filtrate was separated and, after 24 hours, the filtrate was mixed with $\mathrm{HCl}$ pro analyze until the $\mathrm{pH}$ value was 2 . The mixture was precipitated for 24 hours to separate the humic and fulvic acid. Humic acid and fulvic acid separation was done using whatman 42 filter paper. The pasta-shaped part was humic acid and the liquid part was fulvic acid. The pasta-shaped part was dried and mixed with NPK fertilizer. Humic acid was applied 3 times, following the application of NPK fertilizer. Percentage of humic acid application was based on the amount of NPK 16:16:16 fertilizer given, which was 350 kg.ha- ${ }^{-1}$. Fertilization of NPK was applied 3 times, i.e. $100 \mathrm{~kg} \cdot \mathrm{ha}^{-1}$ (2.1 g per plant) at 1 week after planting (WAP), $150 \mathrm{~kg} \cdot \mathrm{ha}^{-1}$ (3.15 g per plant) at 3 weeks after planting (WAP) and $100 \mathrm{~kg} \cdot \mathrm{ha}^{-1}(2.1 \mathrm{~g}$ per plant) at 7 weeks after planting (WAP). The mixture of NPK fertilizer and humic acid was applied by spot placement method.

The maize seeds were sown on acid soils placed in polybags with a diameter of $35 \mathrm{~cm}$ and a depth of $40 \mathrm{~cm}$, arranged in pot spacing of $70 \times 30 \mathrm{~cm}$. The seeds were sown with dibbling method by making a hole with a depth of about 3-5 cm, and the seeds were put in the planting hole of each polybag. The variables observed during the experiment were soil 
chemical properties, plant growth components, and plant yields. Soil chemical properties consist of soil $\mathrm{pH}$ of $\mathrm{H}_{2} \mathrm{O}, \mathrm{C}$-humic content of soil (\%), Al-dd, and available P (P-Bray).

Plant growth variables observed included root length, normal leaf area (green leaf), P deficient leaf area (purple leaf), plant height, stem diameter, root dry weight, shoot dry weight, total plant dry weight, harvest index, and kernel dry weight. Root length $(\mathrm{cm})$ and surface area $\left(\mathrm{cm}^{2}\right)$ were measured using WD3 WinDIAS Leaf Image Analysis System with object mode for measuring root length and area mode for measuring root surface area. The normal leaf area $\left(\mathrm{cm}^{2}\right)$ and area of P deficient leaf $\left(\mathrm{cm}^{2}\right)$ were measured using WD3 WinDIAS Leaf Image Analysis System by separating green leaf area as normal leaf area and purple leaf area as deficiency $\mathrm{P}$ leaf area, using area mode. Plant height $(\mathrm{cm})$ and stem diameter $(\mathrm{cm})$ were measured using ruler and caliper, respectively. Root dry weight (g), shoot dry weight (g), total plant dry weight (g), and kernel dry weight $(\mathrm{g})$ were measured using digital scale. Harvest index was the result of the proportion of kernel dry weight to the total plant dry weight. Plant growth variables were measured at 7 weeks after planting (WAP) (vegetative phase) and 10 weeks after planting (WAP) (silking phase). The data were analyzed with analysis of variance (ANOVA), continued with Duncan Multiple Range Test (DMRT) at $\mathrm{P} \leq 0.05$ to identify significant differences between treatment means, using SAS 9.3.

\section{RESULTS AND DISCUSSION}

\section{Soil chemical properties before and after humic acid application}

Acid soil has some characteristics that inhibit plant growth and yield. The result showed that $\mathrm{pH}$ of acid soil was acidic with low $\mathrm{N}$ and $\mathrm{K}$, very low $\mathrm{P}$ availability, and very high content of the total (Table 1).

Table 1. Soil characteristic before application of mixture NPK fertilizer and humic acid

\begin{tabular}{|c|c|c|}
\hline Parameters & Value & Status* \\
\hline \multicolumn{3}{|l|}{ Physical properties } \\
\hline Sand $(\%)$ & 7.53 & Clay \\
\hline Silt (\%) & 19.12 & \\
\hline Clay $(\%)$ & 73.35 & \\
\hline \multicolumn{3}{|l|}{ pH } \\
\hline $\mathrm{pH}\left(\mathrm{H}_{2} \mathrm{O} \quad 1: 2,5\right)$ & 5.1 & Acid \\
\hline $\mathrm{pH}(\mathrm{KCl} 1: 5)$ & 4.3 & \\
\hline \multicolumn{3}{|l|}{ Organic matter (\%) } \\
\hline Total N (\%) & 0.11 & Low \\
\hline C-org $(\%)$ & 2.17 & Medium \\
\hline Available P- Bray 1 (ppm) & 2.69 & Very low \\
\hline $\mathrm{K}\left(\operatorname{cmol}(+) \mathrm{kg}^{-1}\right)$ & 0.38 & Low \\
\hline $\mathrm{Na}\left(\mathrm{cmol}(+) \mathrm{kg}^{-1}\right)$ & 0.02 & Very low \\
\hline $\mathrm{Ca}\left(\mathrm{cmol}(+) \mathrm{kg}^{-1}\right)$ & 11.89 & High \\
\hline $\operatorname{Mg}\left(\operatorname{cmol}(+) \mathrm{kg}^{-1}\right)$ & 4.26 & Highi \\
\hline Total P (\%) & 0.15 & Very high \\
\hline Kemasaman dd $\left(\mathrm{cmol}(+) \mathrm{kg}^{-1}\right)$ & 1.00 & \\
\hline Exchangable $\mathrm{Al}\left(\mathrm{cmol}(+) \mathrm{kg}^{-1}\right)$ & 0.69 & \\
\hline Exchangable $\mathrm{H}\left(\mathrm{cmol}(+) \mathrm{kg}^{-1}\right)$ & 0.28 & \\
\hline Total Fe $(\%)$ & 3.11 & \\
\hline C humic $(\%)$ & 0.06 & \\
\hline C Fulvic (\%) & 0.08 & \\
\hline $\mathrm{CEC}\left(\mathrm{cmol}(+) \mathrm{kg}^{-1}\right)$ & 27.85 & High \\
\hline
\end{tabular}

Remarks: (*) Status based on Balai Penelitian Tanah (2009) 
Table 2. $\mathrm{Ph} \mathrm{H} \mathrm{H}_{2} \mathrm{O}$, C-Humic content (\%), Exchangeable-Al (c mol (+) $\mathrm{kg}^{-1}$ ), and $\mathrm{P}$ available $\left(\mathrm{mg} \mathrm{kg}^{-1}\right)$ in7 and 15 weeks after planting (WAP) on acid soils affected by mixture of NPK and humic acid (HA) application

\begin{tabular}{|c|c|c|c|c|c|c|c|c|c|}
\hline \multirow{2}{*}{ Treatment } & \multicolumn{2}{|c|}{$\mathrm{pH} \mathrm{H}_{2} \mathrm{O}$} & \multicolumn{2}{|c|}{$\begin{array}{c}\text { C-Humic } \\
\text { Content }\end{array}$} & $\begin{array}{c}\text { Exchangeable } \\
\mathrm{Al} *\end{array}$ & \multicolumn{4}{|c|}{$\begin{array}{c}\text { Soil P } \\
\text { Availability* }\end{array}$} \\
\hline & 7 WAP & 15 WAP & 7 WAP & 15 WAP & 15 WAP & 7 WAP & Status & 15 WAP & Status \\
\hline \multicolumn{10}{|l|}{ Cultivar } \\
\hline Bisi 2 & $4.85 \mathrm{p}$ & $5.53 \mathrm{p}$ & $0.03 \mathrm{p}$ & $0.04 \mathrm{q}$ & $0.80 \mathrm{p}$ & $1.04 \mathrm{p}$ & v.1 & $7.74 \mathrm{p}$ & 1 \\
\hline Pioneer 35 & $4.96 \mathrm{p}$ & $5.45 \mathrm{p}$ & $0.02 \mathrm{q}$ & $0.05 \mathrm{p}$ & $1.03 \mathrm{p}$ & $1.21 \mathrm{p}$ & v.1 & $3.55 \mathrm{p}$ & 1 \\
\hline \multicolumn{10}{|c|}{ Humic Acid Application } \\
\hline $\mathrm{NO} \mathrm{NPK}+\mathrm{HA}$ & $4.95 \mathrm{a}$ & $5.61 \mathrm{a}$ & $0.02 \mathrm{ab}$ & $0.03 \mathrm{c}$ & $0.72 \mathrm{a}$ & $1.50 \mathrm{a}$ & v.1 & $3.20 \mathrm{~b}$ & v.1 \\
\hline NPK & $4.90 \mathrm{a}$ & $5.49 \mathrm{a}$ & $0.03 \mathrm{a}$ & $0.04 \mathrm{~b}$ & $0.78 \mathrm{a}$ & $0.72 \mathrm{a}$ & v.1 & $2.78 \mathrm{ab}$ & v.1 \\
\hline NPK+HA $5 \%$ & $4.79 \mathrm{a}$ & $5.49 \mathrm{a}$ & $0.02 \mathrm{ab}$ & $0.04 \mathrm{~b}$ & $1.44 \mathrm{a}$ & $1.61 \mathrm{a}$ & v.1 & $10.23 \mathrm{a}$ & Med \\
\hline NPK+HA $10 \%$ & $4.95 \mathrm{a}$ & $5.55 \mathrm{a}$ & $0.02 \mathrm{a}$ & $0.05 \mathrm{a}$ & $0.59 \mathrm{a}$ & $0.61 \mathrm{a}$ & v.1 & $4.37 \mathrm{ab}$ & 1 \\
\hline NPK+HA $15 \%$ & $4.93 \mathrm{a}$ & $5.31 \mathrm{a}$ & $0.01 \mathrm{~b}$ & $0.05 \mathrm{a}$ & $1.05 \mathrm{a}$ & $1.18 \mathrm{a}$ & v.1 & $7.65 \mathrm{ab}$ & 1 \\
\hline Interaction & $(-)$ & $(-)$ & $(-)$ & $(-)$ & $(-)$ & $(-)$ & & $(-)$ & \\
\hline$\overline{\mathrm{CV}}$ & 3.90 & 6.07 & 25.06 & 13.75 & 13.55 & 21.51 & & 29.43 & \\
\hline
\end{tabular}

Remark: Means followed by the same letters in the same column are not significantly different according to DMRT ( $\alpha$ 5\%). (-) shows there is no interaction between two factors, $(*)$ shows the data transformed using $\sqrt{ }(\mathrm{x}+0.5)$. Status of $\mathrm{P}$ level was based on Balai Penelitian Tanah (2009) v.l = very low, l = low, med = medium.

Some of soil chemical properties affected by humic acid application in different doses are presented in Table 2. There was no interaction effect between humic acid application and maize cultivars on $\mathrm{pH}$ $\mathrm{H}_{2} \mathrm{O}$, C-humic content, exchangeable $\mathrm{Al}$, and availability $\mathrm{P}$ in the soil. Two maize cultivars and humic acid doses applied had no significant effect on the soil $\mathrm{pH}$ values at 7 WAP and $15 \mathrm{WAP}, \mathrm{C}$-humic content at 7 WAP, and exchangeable $\mathrm{Al}$ at 15 WAP (Table 1). At 7 WAP, the plants were in the final vegetative phase and at 15 WAP, the plants were harvested. Different conditions were observed in the $\mathrm{C}$-humic content affected by maize cultivars and doses of humic acid. The soil planted with Bisi 2 had a higher C-humic content at 7 WAP, but at 15 WAP, the C-humic content of the soil planted with Pioneer 35 was significantly higher.

The effect of humic acid application on the increase in $\mathrm{C}$-humic content was shown at 15 WAP. There was an increase in soil C-humic content along with the increasing dose of applied humic acid. Its application at doses of $10 \%$ and $15 \%$ indicated significant $(\mathrm{P} \leq 0.05)$ effect on the increase in $\mathrm{C}$-humic content. The increase in soil C-humic content at $15 \mathrm{WAP}$ was due to the accumulation of humic acid applied. Meanwhile, there was an increase in $\mathrm{pH}$ that would decrease the complexity of humic acid, resulting in the increase of the soil components such as $\mathrm{Al}$ and clays in the extraction of C-humic content. However, the increased C-humic content was still in very low categories. Although the soil $\mathrm{C}$-humic content increased, there was no significant effect between the maize cultivars and humic acid doses applied on the exchangeable Al at 15 WAP. The increase in C-humic content at 15 WAP was followed by an increase in the $P$ availability at 15 WAP. The application of humic acid did not increase the $P$ availability at 7 WAP, but by the time, increased the $P$ availability at 15 WAP.

The application of humic acid at doses of $5 \%$, $10 \%$, and $15 \%$ increased the status of $P$ availability in the soil. This result showed that the application of humic acid at 5\% significantly turned soil $P$ availability status from very low into medium at 15 WAP. Meanwhile, humic acid application at 10\% and 15\% had the same effect, turning the soil $\mathrm{P}$ availability status from very low into low. An increase in the availability of $\mathrm{P}$ in this area was associated with the humic acid application. The application of humic acid increased the movement and concentration of soil $\mathrm{P}$ availability around humic acid applied. It showed that there was more $\mathrm{P}$ residue in the soil to which the humic acid applied (Zhu et al., 2018).

\section{Effect of humic acid application to acid soil on the maize plant growth and yield}

Root is the part of plant that firstly responses to acid soil conditions. There were no interaction effects between the maize cultivars and doses of humic acid on the root length and root surface area (Table 3). Root length and root surface area were also not different between two cultivars used. Root length and root surface area of maize palnted on acid soil without fertilization was significantly lower than 
Table 3. Root length and root surface area of two corn cultivars at 10 WAP on acid soils affected by by mixture of NPK humic acid application

\begin{tabular}{lcc}
\hline Treatment & Root length $(\mathrm{cm})$ & root surface area $\left(\mathrm{cm}^{2}\right)$ \\
\hline Cultivar & 10 WAP & 10 WAP* \\
Bisi 2 & $11492.16 \mathrm{p}$ & $488.76 \mathrm{p}$ \\
Pioneer 35 & $11750.54 \mathrm{p}$ & $429.66 \mathrm{p}$ \\
\hline Humic Acid Application & & \\
\hline No NPK+HA & $4270.74 \mathrm{~b}$ & $212.86 \mathrm{~b}$ \\
NPK & $15316.76 \mathrm{a}$ & $548.01 \mathrm{a}$ \\
NPK+HA 5\% & $13950.70 \mathrm{a}$ & $527.48 \mathrm{a}$ \\
NPK+HA 10\% & $12878.72 \mathrm{a}$ & $420.02 \mathrm{a}$ \\
NPK+HA 15\% & $11689.86 \mathrm{a}$ & $587.68 \mathrm{a}$ \\
\hline Interaction & $(-)$ & $(-)$ \\
\hline CV $\quad 36.92$ & 22.04 \\
\hline Remark: Means followed by the same letters in the same column are not significantly \\
$\quad$ different according to DMRT $(\alpha \%)$ (-) shows there is no interaction
\end{tabular}

Table 4. Number of leaves, green leaf area, percentage of purple leaf area of two corn cultivars at 10 WAP on acid soils affected by by mixture of NPK humic acid application

\begin{tabular}{lccc}
\hline Treatment & $\begin{array}{c}\text { Number } \\
\text { of leaves }\end{array}$ & $\begin{array}{c}\text { Green leaf } \\
\text { area }\left(\mathrm{cm}^{2}\right)\end{array}$ & $\begin{array}{c}\text { Percentage of purple } \\
\text { leaf area (\%) }\end{array}$ \\
\hline Cultivar & 7 WAP & 10 WAP & 10 WAP* \\
Bisi 2 & $6 \mathrm{p}$ & $3305.85 \mathrm{p}$ & $0.32 \mathrm{p}$ \\
Pioneer 35 & $6 \mathrm{p}$ & $3480.47 \mathrm{p}$ & $0.22 \mathrm{p}$ \\
\hline Humic Acid Application & $3 \mathrm{~b}$ & \\
No NPK+HA & $6 \mathrm{a}$ & $463.04 \mathrm{~b}$ & $1.16 \mathrm{~b}$ \\
NPK & $6 \mathrm{a}$ & $4184.66 \mathrm{a}$ & $0.04 \mathrm{a}$ \\
NPK+HA 5\% & $7 \mathrm{a}$ & $4425.34 \mathrm{a}$ & $0.05 \mathrm{a}$ \\
NPK+HA 10\% & $8 \mathrm{a}$ & $4029.09 \mathrm{a}$ & $0.06 \mathrm{a}$ \\
NPK+HA 15\% & $(-)$ & $3863.65 \mathrm{a}$ & $0.03 \mathrm{a}$ \\
\hline Interaction & 13.55 & $(-)$ & $(-)$ \\
\hline CV $\quad$ DMRT $(\alpha \%) .(-)$ shows there is no interaction between two factors, $(*)$ shows the data transformed \\
\hline Remark: Means followed by the same letters in the same column are not significantly different according to
\end{tabular}

those planted on acid soil with fertilizers. Humic acid application at 5\%,10\%, and $15 \%$ did not significantly affect root length and root surface area. Although the $P$ availability of the soil was increased at $15 \%$ humic acid application, it was not followed by the improvement in the root growth. Wen et al. (2017) reported that the responses of the root, both morphologically and physiologically, had a closer relationship with the P uptake than with the content of P in the soil. Another study reported that humic acid increased the growth variables of cucumber roots when it was applied directly to the root after the seedlings were transplanted (Mora et al., 2012).

Leaf is one part of shoot growth of plant that has a major role for photosynthesis. There was a correlation of $88.6 \%$ between leaf area and photosynthesis rate due to $\mathrm{N}$ fertilization (Sonbai et al., 2013). The results of this study showed that there was no interaction effect between maize cultivars and doses of humic acid applied on the number of leaves, green leaf area, and percentage of leaf area that showed $\mathrm{P}$ deficient symptom (Table 4). Number of leaves, green leaf area, and percentage of leaf area that showed $\mathrm{P}$ deficient symptom were not affected by the maize 
Table 5. Plant height and stem diameter of two corn cultivars at 7 WAP on acid soils affected by by mixture of NPK humic acid application

\begin{tabular}{|c|c|c|c|c|c|c|c|}
\hline \multirow{2}{*}{ Parameter } & \multirow{2}{*}{ Cultivar } & \multicolumn{5}{|c|}{ HA Application } & \multirow[t]{2}{*}{ Means } \\
\hline & & No NPK+HA & NPK & $\mathrm{NPK}+\mathrm{HA} 5 \%$ & NPK+HA $10 \%$ & $\mathrm{NPK}+\mathrm{HA} 15 \%$ & \\
\hline \multirow{4}{*}{$\begin{array}{l}\text { Plant Height } \\
(\mathrm{cm})\end{array}$} & BISI 2 & 65.17 & 137.67 & 150.33 & 148.83 & 146.50 & $129.70 \mathrm{p}$ \\
\hline & Pioneer 35 & 60.67 & 142.5 & 140.5 & 124.83 & 141.75 & $122.05 \mathrm{p}$ \\
\hline & Means & $62.92 \mathrm{~b}$ & $140.08 \mathrm{a}$ & $145.42 \mathrm{a}$ & $136.83 \mathrm{a}$ & $144.13 \mathrm{a}$ & $(-)$ \\
\hline & $\overline{\mathrm{CV}}$ & 14.38 & & & & & \\
\hline \multirow{4}{*}{$\begin{array}{l}\text { Stem Diameter } \\
(\mathrm{mm})\end{array}$} & BISI 2 & $8.87 \mathrm{e}$ & $18.92 \mathrm{bcd}$ & $21.16 \mathrm{a}$ & $19.27 \mathrm{abc}$ & $19.38 \mathrm{ab}$ & 17.52 \\
\hline & Pioneer 35 & $8.83 \mathrm{e}$ & $17.38 \mathrm{bcd}$ & $16.98 \mathrm{~d}$ & $17.17 \mathrm{~cd}$ & $18.47 \mathrm{bcd}$ & 15.77 \\
\hline & Means & 8.85 & 18.15 & 19.07 & 18.22 & 18.93 & $(+)$ \\
\hline & $\mathrm{CV}$ & 10.03 & & & & & \\
\hline
\end{tabular}

Remark: Means followed by the same letters in the same column are not significantly different according to DMRT $(\alpha$ 5\%). (-) shows there is no interaction between two factors, and $(+)$ shows there is interaction between two factors.

cultivars. Fertilization on acid soil significantly increased the number of leaves, green leaf area, and percentage of leaf area that showed P deficient symptom at $10 \mathrm{WAP}$. On the other hand, the application of humic acid at different doses did not significantly affect them. Symptom of P deficiency was shown by the appearance of purple color on the leaves due to sugar accumulation in leaf tissue and the expression of phenolic pigment as a response to abiotic stress (Gardner, 2008). The increase in purple leaf area will decrease the capacity of plants in photosynthesis. Environmental conditions may affect the rate of photosynthesis during the growth process. Rahayuningsih et al. (2017) reported that the presence of water logging in maize occurred at flowering (7 WAP), which could significantly decrease the rate of photosynthesis in some maize cultivars that are intolerant to the stress conditions. The decline in photosynthesis rate was due to the decrease in leaf area on acid soil. In this study, the application of $5 \%, 10 \%$, and $15 \%$ humic acid did not significantly increase the number of leaves and green leaf area compared to the application of NPK fertilizer. The result showed that an increase in soil $\mathrm{P}$ availability status did not affect the growth of green leaf area.

Plant height and stem diameter were not affected by the interaction of maize cultivars and doses of humic acid applied (Table 5). The maize cultivar did not affect the plant height, while the fertilization on acid soil significantly increased the plant height and stem diameter of the maize plants. On the other hand, the application of humic acid at different doses had no significant effect compared to NPK fertilization without humic acid application. However, each maize cultivar had different morphological response to environmental condition. Suwardi and Azrai
(2013) reported that maize cultivars that are not resistant to acid soil conditions experienced a decrease in plant height. Both cultivars used in this study were shorter than the potential plant height, where the potential height of cultivar Bisi 2 is $232 \mathrm{~cm}$ and the Pioneer 35 is $256 \mathrm{~cm}$ (Badan Penelitian dan Pengembangan Tanaman Pertanian, 2012). These conditions represented the same responses of both cultivars to acid soil condition. The application of NPK fertilizer $+5 \%$ humic acid significantly increased the stem diameter of maize cultivar Bisi 2. However, there were no significant differences observed on the stem diameter of maize cultivar Pioneer 35 . An increase in soil $\mathrm{P}$ availability did not affect the plant growth of the maize cultivars tested in this study.

The effect of humic acid application on acid soils was also showed in the accumulation of plant photosynthate in the shoot and root. Photosynthate translocated to leaves, stems, flowers, roots, and ear are showed as total dry weight of the plant. An increase in P availability in the soil was followed by the increase in the shoot biomass and micro nutrients uptake of maize plants (Zhang et al., 2017). Although the increase in soil $\mathrm{P}$ availability was not followed by plant growth in this study, there was an increase in plant biomass (Table 6). There was no interaction effect between maize cultivars and doses of humic acid applied on the root dry weight, shoot dry weight, and total plant dry weight at 10 and 15 WAP. There were no significant effects on root, shoot, and plant total dry weight affected by maize cultivar, except on the total dry weight of the plants at harvest (15 WAP). Cultivar Bisi 2 had a total dry weight which was significantly higher than that of cultivar Pioneer 35. The ability of Bisi 2 to grow well on 0-100 $\mathrm{m}$ asl might play the role for accumulating biomass. 
Table 6. Root dry weight, shoot dry weight and total plant dry weight of two corn cultivars at 10 WAP and 15 WAP on acid soils affected by by mixture of NPK humic acid application

\begin{tabular}{lcccccc}
\hline \multirow{2}{*}{ Treatment } & \multicolumn{2}{c}{ Root dry weight $(\mathrm{g})$} & \multicolumn{2}{c}{ Shoot dry weight $(\mathrm{g})$} & \multicolumn{2}{c}{ Total plant dry weight $(\mathrm{g})$} \\
\cline { 2 - 7 } & 10 WAP* & 15 WAP* & 10 WAP & 15 WAP & 10 WAP & 15 WAP \\
\hline Cultivar & $33.30 \mathrm{p}$ & $27.52 \mathrm{p}$ & $73.05 \mathrm{p}$ & $135.79 \mathrm{p}$ & $106.35 \mathrm{p}$ & $163.32 \mathrm{p}$ \\
Bisi 2 & $27.96 \mathrm{p}$ & $26.29 \mathrm{p}$ & $74.65 \mathrm{p}$ & $123.81 \mathrm{p}$ & $102.61 \mathrm{p}$ & $150.09 \mathrm{q}$ \\
Pioneer 35 & & & & & & \\
\hline Humic Acid Application & $8.42 \mathrm{~b}$ & $5.60 \mathrm{~b}$ & $5.96 \mathrm{~b}$ & $15.26 \mathrm{~b}$ & $14.38 \mathrm{~b}$ & $20.86 \mathrm{c}$ \\
\hline No NPK+HA & $38.64 \mathrm{a}$ & $26.96 \mathrm{a}$ & $89.26 \mathrm{a}$ & $151.13 \mathrm{a}$ & $127.89 \mathrm{a}$ & $178.09 \mathrm{~b}$ \\
NPK & $34.24 \mathrm{a}$ & $31.44 \mathrm{a}$ & $103.21 \mathrm{a}$ & $157.14 \mathrm{a}$ & $137.44 \mathrm{a}$ & $188.58 \mathrm{ab}$ \\
NPK+HA 5\% & $34.96 \mathrm{a}$ & $33.44 \mathrm{a}$ & $80.22 \mathrm{a}$ & $161.07 \mathrm{a}$ & $115.18 \mathrm{a}$ & $194.52 \mathrm{ab}$ \\
NPK+HA 10\% & $36.88 \mathrm{a}$ & $37.09 \mathrm{a}$ & $90.62 \mathrm{a}$ & $164.39 \mathrm{a}$ & $127.50 \mathrm{a}$ & $201.49 \mathrm{a}$ \\
NPK+HA 15\% & $(-)$ & $(-)$ & $(-)$ & $(-)$ & $(-)$ & $(-)$ \\
\hline Interaction & 23.32 & 18.80 & 26.26 & 11.13 & 24.57 & 15.57 \\
\hline CV & & & & & \\
\hline Rema
\end{tabular}

Remark: The mean in one column followed by the same letter was not significantly different according to DMRT $(\alpha$ 5\%). (-) : There were no interaction between two factors, $\left(^{*}\right)$ showed the data transformed used $\sqrt{ }(x+0.5)$.

Table 7. Harvest Index (HI) and kernel dry weight of two maize cultivars on acid soils treated with NPK and humic acid at harvest (15 WAP)

\begin{tabular}{lcc}
\hline Treatment & Harvest Index & $\begin{array}{c}\text { Kernel Dry Weight } \\
\text { (g per plant) }\end{array}$ \\
\hline Cultivar & $0.32 \mathrm{p}$ & $62.07 \mathrm{p}$ \\
Bisi 2 & $0.34 \mathrm{p}$ & $61.04 \mathrm{p}$ \\
Pioneer 35 & & $1.89 \mathrm{c}$ \\
\hline Humic Acid Application & $0.04 \mathrm{~b}$ & $67.42 \mathrm{~b}$ \\
\hline No NPK+HA & $0.38 \mathrm{a}$ & $78.48 \mathrm{ab}$ \\
NPK & $0.42 \mathrm{a}$ & $77.43 \mathrm{ab}$ \\
NPK+HA 5\% & $0.40 \mathrm{a}$ & $82.56 \mathrm{a}$ \\
NPK+HA 10\% & $0.41 \mathrm{a}$ & $(-)$ \\
NPK+HA 15\% & $(-)$ & 23.03 \\
\hline Interaction & 25.58 &
\end{tabular}

Remark: Means followed by the same letters in the same column are not significantly different according to DMRT ( $\alpha 5 \%)$. (-) shows there is no interaction between two factors.

The application of humic acid at different doses had no significant effect on the root and shoot dry weight, however the effect was observed on the total dry weight of plant at 15WAP. The application of humic acid at $15 \%$ significantly increased the total plant dry weight at harvest (15 WAP). Maize is not able to maintain the accumulation of plant biomass under stress conditions (Suwa et al., 2010). The allocation of photosynthate is used for formation of small roots rather than as a root biomass former (Wen et al., 2017), however, the accumulation of photosynthate in the shoot was directly related to crop productivity (Hirte et al., 2018).
Biomass partitioning to kernel dry weight per plant is indicated by the value of harvest index. There was no interaction effect between maize cultivars and doses of humic acid applied on the harvest index and kernel dry weight (Table 7). There was also no significant effect of maize cultivars and doses of humic acid on the harvest index. However, the NPK fertilization on acid soil significantly increased harvest index. An increase in the harvest index of maize crops showed that there was an increase in the distribution of biomass on kernel. The amount of photosynthate translocated to the kernel is indicated by the kernel dry weight. Fertilization on acid soil 
significantly increased kernel dry weight per plant. The application of humic acid at $5 \%$ and $10 \%$ did not significantly give different effects compared to the application pf NPK fertilizer without humic acid application. However, the application of humic acid at $15 \%$ significantly increased kernel dry weight per plant. It was followed by a significant increase in productivity.

The results showed that the application of humic acid at $15 \%$ significantly increased total dry weight and kernel dry weight up to $13.14 \%$ and $21.81 \%$, respectively, when compared with those fertilized by NPK fertilizer without humic acid application during its growth. Rivera-Hernández et al. (2010) reported that harvest index had no direct relationship with the soil $\mathrm{P}$ availability, but it is related to the partitioning of photosynthate as yield. It showed that there was indirect effect of the increase in soil $\mathrm{P}$ availability on the accumulation of plant biomass, especially on kernel. Canellas et al. (2015) also reported that $\mathrm{P}$ deficiency led to decreasing dry weight by reducing the number of kernel per plant, and the application of humic acid increased productivity by increasing efficiency of nutrient absorption and increasing tolerance of stress conditions.

\section{CONCLUSIONS}

The results showed that humic acid application on acid soil increased soil C-humic content, soil P availability, total dry weight of plant, kernel dry weight, and productivity at harvest (15 WAP). The application of humic acid at $15 \%\left(52.5 \mathrm{~kg} \cdot \mathrm{ha}^{-1}\right)$ significantly increased total dry weight of plant and kernel dry weight up to $13.14 \%$ and $21.81 \%$, respectively. Therefore, its application is recommended on maize cultivation on acid soil.

\section{ACKNOWLEDGEMENT}

The authors would like to express deep gratitude to DIKTI (Directorate General of Higher Education) for the funding provided for this research.

\section{REFERENCES}

Azeem, K., S.K. Khalil, F. Khan, A. Qahar and M. Sharif, 2014. Phenology, yield and yield components of maize as affected by humic acid and nitrogen. Journal of Agricultural Science, 6: 286-293.
Badan Penelitian dan Pengembangan Tanaman Pertanian. 2012. Deskripsi varietas unggul jagung. Pusat Penelitian dan Pengembangan Tanaman Pangan Badan Penelitian dan Pengembangan Pertanian Kementerian Pertanian. Maros: Kementerian Pertanian.

Canellas, L.P., F.L. Olivares N.O. Aguiar, D.L. Jones, A. Nebbioso, P. Mazzei and A. Piccolo. 2015. Humic and fulvic acids as biostimulants in horticulture. Scientia Horticulturae, 196: 15-27.

Daur, I. and A.A. Bakhashwain. 2013. Effect of humic acid on growth and quality of maize fodder production. Pakistan Journal of Botany, 45: 21-25.

Fauziah, A. B. .2009. Pengaruh Asam Humat dan Kompos Aktif untuk Memperbaiki Sifat Tailing dengan Indikator Pertumbuhan Tinggi Semai. Skripsi. Institut Pertanian Bogor.

Haynes, R. J. and M.S. Mokolobate. 2001. Amelioration of $\mathrm{Al}$ toxicity and $\mathrm{P}$ deficiency in acid soils by additions of organic residues: A critical review of the phenomenon and the mechanisms involved. Nutrient Cycling in Agroecosystems, 59: 47-63.

Hirte, J., J. Leifeld, S. Abiven and J. Mayer. 2018. Maize and wheat root biomass, vertical distribution, and size class as affected by fertilization intensity in two long-term field trials. Field Crops Research, 216: 197-208.

Kementerian Pertanian. 2016. Outlook Komoditas Pertanian Tanaman Pangan Jagung. Jakarta.

Mora, V., R. Baigorri, E. Bacaicoa, A.M. Zamarreño and J.M. García-Mina. 2012. The humic acidinduced changes in the root concentration of nitric oxide, IAA and ethylene do not explain the changes in root architecture caused by humic acid in cucumber. Environmental and Experimental Botany, 76: 24-32.

Mulyani, A., A. Rachman and A. Dariah. 2009. Penyebaran lahan masam, potensi dan ketersediaannya untuk pengembangan pertanian. Fosfat Alam: Pemanfaatan Pupuk Fosfat Alam Sebagai Sumber Pupuk P. http://balittanah. litbang.pertanian.go.id/ind/dokumentasi /buku/fosfatalam/anny_mulyani.pdf.

Rahayuningsih, S. E. A., D. Indradewa, E. Sulistyaningsih and A. Maas. 2017. The tolerance of photosynthesis of some maize cultivars (Zea mays L.) to waterlogging at different stages of growth. International Journal on Advanced Science, Engineering and Information Technology, 7: 1296-1301. 
Rivera-Hernández, B., E. Carrillo-Ávila, J.J. ObradorOlán, J.F. Juárez-López and L.A. AcevesNavarro. 2010. Morphological quality of sweet corn (Zea mays L.) ears as response to soil moisture tension and phosphate fertilization in Campeche, Mexico. Agricultural Water Management, 97: 1365-1374.

Sajedi, N. A., M.R. Ardakani, F. Rejali, F. Mohabbati and M. Miransari. 2010. Yield and yield components of hybrid corn (Zea mays L.) as affected by mycorrhizal symbiosis and zinc sulfate under drought stress. Physiology and Molecular Biology of Plants, 16: 343-351.

Sonbai, J. H. H., D. Prajitno and A. Syukur. 2013. Pertumbuhan dan hasil jagung pada berbagai pemberian pupuk nitrogen di lahan kering regosol. Ilmu Pertanian, 16: 77-89.

Suwa, R., H. Hakata, H. Hara, H.A. El-Shemy, J.J. Adu-Gyamfi, N.T. Nguyen and K. Fujita. 2010. High temperature effects on photosynthate partitioning and sugar metabolism during ear expansion in maize (Zea mays L.) genotypes. Plant Physiology and Biochemistry, 48: 124-130.
Suwardi and M. Azrai. 2013. Pengaruh cekaman kekeringan terhadap hasil genotipe jagung. Balai Penelitian Tanaman Serealia p. 139147. In: Seminar nasional Serealia (eds.). Meningkatkan Peran Peneliti Serealia Menuju Pertanian Berkelanjutan, Maros.

Tan, H. 2003. Humic Matter in Soil and the Environment. CRC Press : Boca Raton, FL.

Wen, Z., H. Li, J. Shen and Z. Rengel. 2017. Maize responds to low shoot $\mathrm{P}$ concentration by altering root morphology rather than increasing root exudation. Plant and Soil, 416: 377-389.

Zhang, W., D.Y. Liu, C. Li, X.P. Chen and C.Q. Zou. 2017. Accumulation, partitioning, and bio-availability of micronutrients in summer maize as affected by phosphorus supply. European Journal of Agronomy, 86: 48-59.

Zhu, J., M. Li and M. Whelan. 2018. Phosphorus activators contribute to legacy phosphorus availability in agricultural soils: A review. Science of the Total Environment, 612: 522537.

Zubachtirodin, M.S. Pabbage and Subandi. 2008. Wilayah produksi dan potensi pengembangan jagung. http:// balitsereal. litbang. pertanian. go.id/wp-content/uploads/2016/11/lima.pdf. 